\title{
Introduction
}

\section{Policy Responses to Ageing and the Extension of Working Lives}

\author{
Simon Biggs*, Dina Bowman**, Helen Kimberley*** \\ and Michael McGann ${ }^{\dagger}$
}

*School of Social and Political Sciences, University of Melbourne

E-mail: biggss@unimelb.edu.au

**Research and Policy Centre, Brotherhood of St Laurence. School of Social and Political Sciences, University of
Melbourne
E-mail: dbowman@bsl.org.au
***Research and Policy Centre, Brotherhood of St Laurence
E-mail: hkimberley@bsl.org.au

${ }^{\dagger}$ School of Social and Political Sciences, University of Melbourne

E-mail: mmcgann@unimelb.edu.au

Since the beginning of the twenty-first century, the relationship between work and ageing has become increasingly visible as a policy issue. It is both reflected in and influenced by changes in macro-economic policy, life-opportunities and social attitudes associated with growing older, as a combination of falling birth rates and increased longevity, and has put pressure on the traditional parameters of the working age. The idea of retiring at a fixed point in the life-course, to enjoy a period of rest or leisure at the end of a working life, emerged in many advanced economies during the 1900s and evolved into policies that encouraged early retirement as the baby-boomers entered the jobs market in the 1960s and 1970s (Phillipson and Smith, 2005). Early retirement, itself a relatively recent development, gave rise to the possibility of a 'third age' of leisure and active ageing (Laslett, 1987), but as demographic and economic changes make themselves felt, it is again becoming an uncertain prospect for many older workers (Biggs and McGann, 2015).

Demographic changes explain part of the recent re-emphasis on a long working life. By 2050, the global population aged over sixty is projected to reach two billion, three times more than in 2000 (Bloom, 2011). To take Australia as an example, whereas there were 7.3 people of 'traditional working age' per person aged sixty-five and over in 1975, today there are fewer than five. By 2055, it is projected that this will fall further to just 2.7 working people per person aged sixty-five and over (Australian Government, 2015). Similar trends are apparent across the OECD, prompting forecasts of a looming crisis in pensions funding if longer, healthier lives are not 'matched by longer working lives' (OECD, 2006: 3). If the 'dependency ratio' is as forecast, it is argued, there simply will not be enough workers around to support the rest. While the current question of how to respond to demographic change can be traced to the OECD's 1998 report on Active Ageing, a new concern about the relationship between work and ageing developed with the publication of Ageing and Employment Policies: Live Longer, Work Longer (OECD, 2006). This title alone leaves little to the imagination on how a new historical settlement should play out. Extending 
working life appeared to be an easier political solution to falling dependency ratios than the alternatives of significantly increasing fertility, migration or productivity. It is a view that appears to have become increasingly entrenched following the global financial crisis (GFC) that began in 2008. During the GFC, not only did many advanced economies have to bail out their financial institutions, the political opportunity arose to reengineer public policy and the practices of private corporations. The imposition of austerity measures has varied in scope and severity between countries, and for older people, their effects have been most notable in the area of pensions. Reducing state pension eligibility has become the mechanism of choice for engineering a cultural adaptation to demographic change, while within the sphere of occupational pensions, there has been a corresponding retreat from corporate welfare (Ekerdt, 2010) as defined-benefit pensions have been replaced by market-based contribution schemes (Taylor, 2010). Both developments shift the costs of longevity onto individuals and families. Inter-governmental organisations such as the World Bank and International Monetary Fund have, at the same time, aggressively pushed for a de-collectivisation of retirement funding and an expanded role for private capitalised pension provision (Phillipson, 2013). Arguably, the assumption that the 'problem of ageing' is therefore solved, has now reached hegemonic proportions within the policymaking community.

However, less account has been taken of wider understandings of the role of older adults in society, the diversity amongst older workers in their attitudes to working life or the type and quality of jobs available to them (Vickerstaff, 2010; Loretto and Vickerstaff, 2013). Taken together, the policy shifts that have formed the majority response to population ageing promise a more precarious ageing, one in which the prospect of work offers a similar trajectory of economic insecurity, casualisation and non-progression that has become associated with younger age groups (Biggs, 2014). Research has shown that even in Australia, which managed to avoid many of the excesses of the GFC, the boundary between work and non-work has become increasingly uncertain. Older workers report often being sidelined from work opportunities other than casual and insecure work (Bowman and Kimberley, 2012). Findings from a three-year study, following older workers and underemployed older adults, indicate that an increasing number are experiencing long-term unemployment and insecurity in the labour market, a phenomenon that varies widely depending upon job history and social position. The connective mechanisms that states employ to re-engage older workers appear ill-equipped to meet the needs and aspirations of this group (McGann et al., 2015), especially as ageism in employment needs to be seen through the twin lenses of class and gender (Bowman et al., forthcoming).

This themed section brings together contributions from researchers in Australia and the UK to critically examine the impact of policy responses to population ageing and the extension of working lives on contemporary experiences of adult ageing. The contributions document how the reconfiguration of working lives and pensions is reshaping the meaning of growing old and the identities associated with it, which, since the middle of the twentieth century, have been framed around the social and economic institutions linked to retirement and the welfare state (Phillipson, 2013). In particular, we address how policy developments in the area of ageing and employment are intersecting with the broader characteristics of neo-liberalism and post-industrial societies. The articles examine, from a variety of perspectives, how the changing nature of work and a growing emphasis on individualised risk-bearing (Hamilton, 2014) generate new sources of anxiety, risk and uncertainty for ageing workers. 
The articles address two key issues emerging from these policy developments: the changing nature of work and its implications for older workers and ageing in employment; and welfare state reform and the 'activation' of older workers. The contributions point to the development of a critical research agenda about older workers and economic security in old age.

As Guillemard has argued, 'In an ageing society where people live longer, the worklife can be made longer only if work is bearable for a longer time' (2013: 62). This raises a series of questions about the relationship between contemporary working life and adult ageing. Riach and her co-authors highlight the challenges posed by contemporary patterns of work organisation and management practices to the extension of working lives. They highlight how discourses around the management of age diversity represent age discrimination by managers and recruiters, and see this as a key workplace issue inhibiting the extension of working lives. Both Powell and Taylor and McGann and coauthors draw attention to the shifting policy landscape surrounding employment and retirement funding. Powell and Taylor situate these developments within the broader context of the great risk shift permeating social policy in post-industrial societies. Whereas it has become commonplace to celebrate an individualisation of risk as it contributes to a reflexive reshaping of old age away from structured dependency, Powell and Taylor argue that it has far-reaching dystopian implications for those ageing adults without the resources to adequately manage life-course risks. This is further emphasised in the contribution by McGann et al., which examines the situation of a group of older Australians caught in the netherworld between work and retirement and facing an increasingly precarious experience of adult ageing. This article highlights the scarring uncertainties experienced by marginal older workers and the corrosive effects of social ageism in the jobs market.

The contributions by Deeming and Smyth and Bowman et al. shift attention onto the role of the welfare state in 'activating' older workers. Deeming and Smyth consider the relevance of emerging perspectives on the social investment state for policy responses to population ageing. They argue that 'passive' social policy interventions, associated with the post-war welfare state, are now seen as out of kilter with the needs of a knowledge economy that requires a social investment perspective. As the contribution by Bowman et al. highlights, older jobseekers are a key (and growing) cohort within the group of longterm unemployed jobseekers. They argue that there is a misfit between the perspectives of the relatively young frontline employment services staff and older jobseekers in a system which has not adapted to the increased numbers of white-collar older unemployed workers. This is reflected in the longer durations that older workers who are displaced from their jobs spend unemployed compared with so-called prime-age workers. As Bowman et al. discuss, more than a decade of welfare reform, inspired by the principles of New Public Management, has left the employment services system ill-equipped to deal with the particular needs and circumstances of older jobseekers. Taylor et al. outline the need for a research agenda that critically examines understandings and responses to mature age workforce participation and security. During periods of economic crisis and demographic change, the role older workers play in the labour market comes under increased policy and academic scrutiny. They identify four gaps in current knowledge: who is to be researched; what the focus of that research should be; theory informing the research; and how the research should be conducted. A long view is required to critically frame new and more appropriate questions. 
The selection of views expressed in this themed section highlight some of the complexities associated with ageing and the extension of working lives. As these articles demonstrate, it is more complicated and uncertain than suggested by the simple solutions provided by leading international policy organisations. We trust that out of critique, a new series of insights and more effective policy responses will emerge.

\section{References}

Australian Government (2015) 2015 Intergenerational Report, Commonwealth of Australia.

Biggs, S. (2014) 'Precarious ageing versus the policy of indifference: international trends and the G20', Australasian Journal on Ageing, 33, 4, 226-8.

Biggs, S. and McGann, M. (2015) 'Retirement and social policy', in N. A. Pachana (ed.), Encyclopaedia of Geropsychology, New York: Springer.

Bloom, D. E. (2011) '7 billion and counting', Science, 333, 6042, 562-9.

Bowman, D. and Kimberley, H. (2012) Sidelined! Workplace Participation and Non-Participation among Baby-Boomers in Australia. Melbourne: Brotherhood of St Laurence.

Bowman, D., McGann, M., Kimberley, H. and Biggs, S. (forthcoming) "Rusty, invisible and threatening': Ageing, capital and employability', Work Employment and Society.

Ekerdt, D. J. (2010) 'Frontiers of research on work and retirement', Journal of Gerontology: Social Sciences, 65B, 69-80.

Guillemard, A.-M. (2013) 'Prolonging working life in an aging world: a cross-national perspective on labor market and welfare policies toward active ageing', in J. Field, R. J. Burke and C. L. Cooper (eds.), Handbook of Aging, Work and Society, London: Sage, 60-74.

Hamilton, M. (2014) 'The "new social contract" and the individualisation of risk in policy', Journal of Risk Research, 17, 453-67.

Laslett, P. (1987) 'The emergence of the third age', Ageing and Society, 7, 2, 133-60.

Loretto, W., Lain, D. and Vickerstaff, S. (2013) 'Rethinking retirement: changing realities for older workers and employee relations?', Employee Relations, 35, 3, 248-56.

McGann, M., Bowman, D., Kimberley, H. and Biggs, S. (2015) Too Old to Work, Too Young to Retire, a summary of ARC project Understanding and preventing workforce vulnerabilities in midlife and beyond, http://library.bsl.org.au/jspui/bitstream/1/7905/4/Workforce_ vulnerabilities_in_midlife_and_beyond_research_summary_2015.pdf, Melbourne: Brotherhood of St Laurence.

Organisation for Economic Co-operation and Development (OECD) (1998) Active Ageing, Paris: OECD.

Organisation for Economic Co-operation and Development (OECD) (2006) Ageing and Employment Policies: Live Longer, Work Longer, Paris: OECD.

Phillipson, C. (2013) Ageing, Cambridge: Polity.

Phillipson, C. and Smith, A. (2005) Extending Working Life: A Review Of The Research Literature, Research Report No. 299, Department for Work and Pensions, UK Government, Leeds: HMSO.

Taylor, P. (2010) 'Cross-national trends in work and retirement', in D. Dannerfer and C. Phillipson (eds.), Handbook of Social Gerontology, London: Sage, 540-50.

Vickerstaff, S. (2010) 'Older workers: te unavoidable "obligation" of extending our working lives?', Sociology Compass, 4, 10, 869-79. 